\title{
NEW LIGHT ON FLETCHER V. PECK AND GIBBONS V. OGDEN
}

\author{
WALLACE MENDELSON†
}

IN Gibbons v. Ogden " "for the one and only time in his career on the supreme bench, [Chief Justice] Marshall . . . pronounced a 'popular' opinion." 2 That opinion attained its novel distinction, of course, because it destroyed the hated steamboat monopoly on the Hudson River. Since steam navigation in 1824 was a crucial form of transportation and since the Hudson River was one of the two or three most important highways of national commerce, the unpopularity of the monopoly is easy to understand. ${ }^{3}$ But surely the New York State legislature, which had created the monopoly (to stimulate the development of steam navigation) was not insulated from the heat of popular dissatisfaction with the situation on the Hudson. Why had it not abolished its creature -its purpose having been accomplished-years before protracted litigation came to a weary end in Gibbons a. Onden?

A legislature less in harmony with "popular" social pressures than a court is a phenomenon that invites exploration. In this case, one need go no further for the explanation than John Marshall's earlier opinions in Fletcher v. Peck ${ }^{4}$ and the Dartnouth Collcge case, ${ }^{5}$ where, as Professor Corwin has shown, the doctrine of vested interests was established as the first basic principle of American constitutional law. Both "natural justice" and the clause prohibiting impairment of the obligation of contract, according to Marshall, prohibit a state legislature from modifying its own acts to the detriment of interests which have vested thereunder. The important factor is the sanctity of private property. Even public property (Fletcher $v . P e c k$ ) and the public interest in education (Dartmouth College case) must be subsumed to it. That sentiment, of course, came straight from Blackstone's codification-"so great . . . is the regard of the law for private property, that it will not authorize the least violation of it; no not even for the general good of the whole community." 6

$\uparrow$ Associate Professor of Political Science, University of Ternessee.

1. 9 Wheat. 1 (U.S. 1824).

2. 4 Beverndge, The Life of John Mlanseall 445 (1919). See also 2 Warsan, The Supresie Court in United States History, 71-72 (1923).

3. The holders of the New York monopoly had similar interests on the Mississippi River which they obtained by act of the territorial legislature of Louisians on April 19, 1811. Thus they held the key to the two most important ports in North America.

4. 6 Cranch 87 (U.S. 1810).

5. 4 Wheat. 518 (U.S. 1S19).

6. $1 \mathrm{BL}$. Consas. $* 139$. The Commontarics were first published in Ameriea in 1772. One of the original subscribers was John Mirshall's father, "who saw to it that his son read Blackstone as carefully as circumstances permitted. He had bought the boo!: for Jotn's 
The New York legislature was well aware of the unpopularity of the steamboat monopoly and obviously in sympathy with the desire to abolish it. Memorials and petitions for relief from the Fulton-Living. ston monopoly flooded the Albany legislature between Fletcher v. Peck in 1810 and Gibbons v. Ogden in 1824. At least four select committees studied the matter and came to the same conclusion: the steamboat monopoly was a menace but the doctrine of vested interests-as yet unmitigated by the concept of the police power-prohibited direct legislative relief. The problem then became one of finding indirect methods to accomplish what could not be done directly.

In 1807, the first successful steamboat was launched on New York waters. In the following year, two years before Fletcher v. Peck, the legislature of New York "for the further encouragement of steamboats on the waters of this state" provided that "whenever Robert R. Livingston and Robert Fulton . . . shall establish one or more steamboats or vessels, other than that already established, they shall for each and every such additional boat, be entitled to five years prolongation of their grant or contract with this state [emphasis added]. Provided nevertheless, that the whole term of their exclusive privileges, shall not exceed thirty years after the passage of this act." 7 Although there had been at least five preceding acts on the subject, that of 1808 first used the word "contract" to describe the relation between the state and the steamboat proprietors. Obviously someone had anticipated Fletcher $v$. Peck. ${ }^{8}$ Counsel for opponents of the monopoly threw some light on that point before a state court in 1812. They repudiated the idea of a contract signed, sealed, and delivered between New York and Livingston-Fulton. "The grant wanted all the essential features of a contract, inasmuch as it was gratuitous-without reciprocity or mutual obligation." In short, it was "a mere permission, and the foisting of the word contract, into the last act (which merely extended what prior acts had already 'granted') could not alter the nature of the grant." " That the word "contract" indeed had been "foisted" (by

use as much or more than for his own information." 1 BEvERIDGE, THE LIFE OF JO1rN Marshall 56 (1916).

7. Act of April 9, 1811.

8. An opinion by Alexander Hamilton upon which Marshall obviously drew heavily had been widely circulated in a pamphlet by Harper, The Case of tue Georcta Salis on the Mississippi, with a Reference to Law Authorities and Public Acts (Philadelphia, 1799).

9. See Livingston v. Van Ingen, 9 Johns. 507, 541 (N.Y. 1812). See also DuER, A Repiy to Mr. Colden's Vindication of the Stenur-Bont Monopoly 102 (Albany, 1819) : "the thirty years to which the whole term of the grant appears to have been limitcd by the proviso of this clause (in the act of 1808), is computed 'from the time of the passing of the act' of 1808, instead of from the year 1803, from which the previous term commenced,-thus in fact extending the duration of the whole grant for five years, without any pretense of consideration! A circumstance, which I will venture to say, was as little 
representatives of Livingston and Fulton?) upon an unsuspecting legislature finds support within the act itself. For only a sentence after the word "contract," there follows a proviso which refers to the LivingstonFulton interests as "exclusive privileges" rather than contractual rights.

The unusual use of the word "contract" in the statute pointed the line of defense which the steamboat proprietors persistently used in all clashes with the legislature. Two prominent lawyers, Thomas A. Emmet and Cadwallader D. Colden, represented Fulton and Livingston before the Duer Committee (the first select committee appointed to consider a petition for relief against the monopoly) and also before a "joint" session of the legislature which heard the committee report and arguments against it. ${ }^{10}$ To Emmet and Colden, it was obvious that a contract had been consumated:

"That the nature of the engagement between Messrs. Livingston and Fulton and the state might be well understood, the legislature also spoke of it as a contract. And I ask, has it not all the features of a contract? It is a mutual agreement. On the one hand, Messrs. Livingston and Fulton, offering to spend their money, and to run the risk of employing their steamboats on the waters of this state, provided the legislature will grant them certain privileges; and on the other, the state accede to their propositions, and engage, that if they will effectively employ such boats, they shall have the consideration of an exclusive privilege for a certain time." 11

That argument, based as it was upon Fletcher थ. Peck, was accepted by the Duer Committee; ". . . however inconsistent it be with the spirit of a wise and equitable system of laws, to confer exclusive privileges . . . however contrary to the acknowledged principles of political economy, to grant a monopoly of the elements of invention in one

understood at the time, by those who were not in the secret, as the design by which the word contract was 'foisted' into the act." But, alas, Fletcher z: Pccl: itself protected vested interests predicated in fraud. Indeed that was one of the crucial points at issue in Fletcher v. Peck.

10. Duer, A Letter Addressed to Cadwallader D. Coldes, Esquire In Azswer to the Strictures, Contatned In His LIFe of Robert Fulton, Ufon tye Rerors of

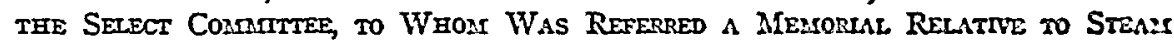
Navigation, Presented to the Legislature of New York, at the Session of 1814 48 (Albany, 1817). Mr. Duer later became President of Columbia College of Nev York.

11. A Vindication, by Cadwallader D. Colden, of the Stensis-Bont Rugit Granted by the State of New York in the Fors of an Axswer to the Letter of Mir. Duer, AdDressed to Mir. Colden 73 (New York, 1819). This position is particularly interesting in view of the opinion dated January 19, 1811 in which Mr. Emmet advised his clients that their monopoly was invalid since "after the adoption of the Federal Constitution no State Legislature had any authority to grant an exclusive right of maling, constructing, or employing any machine or invention." 13 N. Y. LIE3ARY Bull. 573. 
whole department of discovery; yet if the legislature have fallen into this error; if they have actually vested in individuals, rights hostile in their exercise to the general interests; they cannot on that ground avoid or resume their own grant; they alone had authority to judge of the expediency of the measure, and the public faith is bound by their decision." 12

But the Duer Committee was resourceful. An Act of 1811 "for the more effectual enforcement of" the Act of 1808 had given to Livingston and Fulton some extraordinary remedies amounting to outright confiscation of any steamboat violating their "exclusive privileges." The Duer Committee after observing in elaborate detail that the original monopoly of 1808 violated the congressional commerce and patent powers, urged that the Act of 1811 "in effect shuts the courts of justice of this state against any person who may be desirous of bringing to a legal test, the rights claimed by Livingston and Fulton, as by the provisions of that act, the defendant of any suit to be commenced by them . . . must lose his boat and his machinery even if he should eventually gain his cause . . . and as this forms no part of the right of Livingston and Fulton, being only a new remedy given them by that statute, your committee believe there can be no doubt of the right as well as the power of the legislature, so to alter or modify that remedy, as to prevent its working manifest injustice by shutting those courts which in a free country should be left open to every individual." 13

The Committee recognized the sanctity of the "contractual right" (so far as legislative interference was concerned), but at the same time, it wrote an elaborate brief on the national commerce and patent powers for the use of any who might like to have a go in court, and then attempted to distinguish between rights and mere remedies in a way which would make litigation much easier. But as Mr. Justice Cardozo pointed out more than a century later, "In the books there is much talk about distinctions between changes of the substance of the contract and changes of the remedy. The dividing line is at times obscure." ${ }^{14}$ Thus, Messrs. Emmet and Colden in their defense before the "joint" session of the legislature had a ready answer:

"You insist it would be consistent with the faith of the state, to repeal the forfeiture and other remedies given by the statutes . . . you say it would not be contended in any other case that the legislature could not . . . alter, modify or take away remedies . . . for the maintenance of any right whatever. Again, you are most manifestly wrong. It would be contended in any case where the state had made an agreement with individuals, by which private rights

12. DUer, op. cit. supra note 10 , at 8-9.

13. In Assembly, Tuesday, March 8th, 1814. The Committee to whom was referred the Memorial and Petition of Aaron Ogden, a Citizen of the State of New Jersey.

14. Worthen Co. v. Kavanaugh, 295 U. S. 56, 60 (1935). 
were created and vested, and where a consequent benefit was actually given the state, and where the legislature, with the concurrence of the other contracting parties, had established those remedies in order to secure and protect the rights created and vested by the agreement. You illustrate your ideas by a very learned discussion on the remedy of distress, by the insolvent laws, and a repeal of the laws authorizing imprisonment for debt. What they have to do with public faith, I confess I am at a loss to comprehend. Public faith may well be implicated and pledged to support a specific agreement the state has made, and the terms of a particular bargain or the incidental sanctions of that bargain, which the legislature has advisedly assented and acceded to, at the request of the party with whom it made its stipulations; but I see no claim upon public faith that can be used against the modifications of general remedies, founded on no public agreements, enacted only with a view to general policy and expediency, and in no respect stipulated for or entering into the bargains made between the contracting parties themselves." 15

The lower house of the legislature passed the Duer Committee bill for the abolition of the extraordinary remedies by which the monopoly rights were vindicated. But in the Senate, the bill failed of passage by only one vote. ${ }^{16}$ The attempt to circumvent Fletizer v. Peck by the highly technical distinction between rights and remedies failed in the New York legislature by the narrowest possible margin.

Thereafter, numerous other petitions for relief against the monopoly were submitted and five additional select committees were appointed to investigate. Two in $1817^{17}$ and a third in $1822^{18}$ adopted in substance the prior views and recommendations of the Duer Committee. But no legislation altering either the monopoly's rights or its remedies was adopted. In 1817, however, the year in which two select committees reported adversely to the monopoly, the legislature did enact legislation imposing a special tax upon steamboat passengers. The purpose and effect of that tax are indicated indirectly in a petition to the legislature in 1819 in which the monopolists complained of the burden of the $\operatorname{tax}$ and requested either that the state purchase the steamboat business or relieve it of the tax burden. The petition is particularly

15. COLDEN, op. cit. supra note 11 , at 78.

16. DUER, op. cit. supra note 10 , at $80-81$. See also Dickrrssoss, Roders FuLTo:s, ENGINEer AND ARTIST, His Life AND Woriss 252 (1913).

17. Their reports are reproduced in full in DUER, op. cit. supra note 10, appendix Q and $T$.

18. N. Y. Asserrbly Journal S0t-S06 (1822). A select committee of the Assembly in 1820 recommended that no relief be given because the matter had been investigated and rejected so many times previously. N. Y. AssearmLY Jounris 1014-1015 (1820). A Senate select committee in the same year recommended that no relief be given since the matter was then pending in the Supreme Court of the United States. N. Y. SEriste JOURNAL 215-216 (1820). 
interesting because it reveals that the monopolists were quite conscious of the unhappy position in which the legislature found itself, caught as it was between the popular demands for relief and the restrictions of Fletcher v. Peck (by then reinforced by the Dartmouth College case). Thus, "the petitioners suggest, that if the state should accept this offer, it may then throw open the navigation by steam on the Hudson River. . . ." 19 No legislative action was taken in response. Then, in the year after Gibbons v. Ogden, Mr. Colden advises us that "since the Supreme Court of the United States had decided that the grant to Livingston and Fulton ... . was invalid, there has been no attempt to collect the tax on steamboat passengers." ${ }^{20}$ Obviously the legislature, despite the recommendations of four select committees, felt itself powerless under Fletcher v. Peck and the Dartmouth College case to alter either the rights or remedies connected with the steamboat monopoly. But to discourage the Livingston-Fulton interests, it did resort to the tax device and that was immediately abandoned when the monopoly was destroyed by judicial action.

Blackstone's doctrine of vested interests was indeed the first doctrine of American constitutional law. But no society, certainly no democracy, could thrive on the pristine simplicity of such a foundation. Even Marshall came by degrees to recognize that. In Fletcher v. Peck the public interest got rough treatment and little lip service. But eleven years later, in the Dartmouth College case, the idea of the Police Power is suggested:

". . . the framers of the constitution did not intend to restrain the states in the regulation of their civil institutions adopted for internal government." 21

Shortly thereafter, in Gibbons v. Ogden, the Police Power concept becomes quite explicit:

". . . the acknowledged power of the state to regulate its police, its domestic trade and to govern its own citizens may enable it to legislate on this subject to a considerable extent." ${ }^{22}$

and the judge who earlier had subsumed public property (Fletcher $v$. $P e c k$ ) and the public interest in education (Dartmouth College case) to private property recognized that enormously valuable business interests

19. See report of the select committee to whom this petition was referred which is reproduced in CoLDEN, op. cit. supra note 11, at 93-96.

20. Colden, Menor Prepared at the Request of a Commitree of tue Comaron Counch of the City of NEW York and PREsented to the Mayor of New Yome at the Celebration of the Conpletion of the New York Canals 49 (N. Y. 1825).

21. 4 Wheat. 518,629 (U.S. 1819 ).

22. 9 Wheat. 1,208 (U.S. 1824). 
must give way before the public stake in free steam navigation on the Hudson River. ${ }^{23}$ In thus recognizing that private property was not the very apex in social values, and in permitting at least the judiciary to protect public, at the expense of private, interests the "great Chief Justice," as already indicated, wrote his only contemporaneously popular opinion. But Gibbons v. Ogden was merely the first crucial American inroad upon Blackstone's concept of the sanctity of private property. In the first term of court following Marshall's death, Chief Justice Taney-for his Court-established the Police Power concept upon a firm foundation:

"While the rights of property are sacredly guarded, we must not forget, that the community also has rights, and that the happiness and well-being of every citizen depends on their faithful preservation. [The court could not consent to strip away] the rights reserved to the states [and by] mere technical reasoning take away from them any portion of that power over their own internal police and improvement, which is so necessary to their well-being and prosperity." 24

23. In Willson v. Blackbird Marsh Creek Co., 2 Pet. 245 (U.S. 1829), Afarshall goes his farthest in recognizing the Police Power and indeed virtually reverses his Gibbons v. Ogden position. For in the later case he permits a state by means of a dam to obstruct commerce on a navigable stream-even vis-a-vis a vessel operating under a federal cousting license. It was the existence of such a license which had been the crux of the decision adverse to state legislation in Gibbons v. Ogders.

24. In the Charles River Bridge case (11 Pet. 420 (U.S. 1837)), MFarshall's old associate and alter-ego, Mrr. Justice Story, dissented and we know on his authority that Marshall who had heard the case just before his death concurred in Story's views. For such old Federalists as Kent, Story and Webster the Police Power doctrine of the Charles River Bridge case "undermines the very foundations of morality, confidence and truth. ... When we consider the revolution in opinion, in policy, and in numbers that has recently changed the character of the Supreme Court, we can searcely avoid being reduced to a state of dispair for the commonwealth." Kent, 2 N. Y. Revew 387, 402 (April, 1838). For a brief account of the contest between the doctrines of Vested Interests and Police Power from Blackstone and Eentham through Mfarshall and Tancy, see Mendelson, Chief Justice Marshall and the Mercantile Tradition, 29 TrE Sournwestenst Soe. ScI. Q. 27 (June, 1948).

Fletcher v. Peck was in effect overruled in Illinois Central Railroad Co. v. Illinois, 146 U.S. 387, 460 (1882). The facts in the two cases are strilkingly similar except for the absence of any element of fraud in the later case. By 1882 the Court spealing through Mr. Justice Field, was able to hold that "any attempted cession of the ownership and control of the State in and over the submerged lands in Lake Mlichigan, by the ast of April 6,1869 , was inoperative . . . any such attempted operation of the act was annulled by the repealing act of April 15,1873, which to that extent was valid and effective. There can be no irrepealable contract in a conveyance of property by a grantor in disregard of a public trust. ..." 